\title{
Opinions of Preservice Teachers on their Acceptance of the Use of Mobile Technologies For Teaching Purposes ${ }^{*}$
}

\author{
İsmail Tonbuloğlu ${ }^{1}$, Mübin Kıyıc1 ${ }^{2}$ \\ ${ }^{1}$ Informatics, Yildiz Technical University, Istanbul, Turkey \\ ${ }^{2}$ Faculty of Education, Sakarya University, Sakarya, Turkey \\ Correspondence: İsmail Tonbuloğlu, Informatics, Yildiz Technical University, Istanbul, Turkey.
}

Received: February 13, 2018

Accepted: April 20, $2018 \quad$ Online Published: April 23, 2018

doi:10.11114/jets.v6i6.3230

URL: https://doi.org/10.11114/jets.v6i6.3230

\begin{abstract}
The study examines opinions of preservice teachers on their acceptance of the use of mobile technologies for teaching purposes. This study is a phenomenological research. Semi-structured interviews were held with 4 preservice Turkish teachers and 4 preservice Science teachers selected by criterion sampling method. The resulting themes related to opinions of the preservice teachers on their acceptance of the use of mobile technologies for teaching purposes are as follows: "Perceived Usefulness and Ease of Use", "Intention of Use and Attitude Towards Use", "Social Effect", "Individual Competencies", "Integration in Educational Environment" and "Innovation".
\end{abstract}

Keywords: technology acceptance model TAM, mobile technology, mobile teaching, mobile learning, technology integration in education

\section{Introduction}

Smartphones, tablet computers and pocket-sized computers have an important place in our daily lives. The potential for use of mobile devices in all fields is increased by unique qualities of mobile devices such as convenience, customizability and portability. Learning has lately spread to every stage of human life and the concept of lifelong learning has been adopted by individuals, as a result of which mobile devices will inevitably be used and become widespread in learning environments. Another significant factor in diffusion of mobile devices in field of education in Turkey is FATIH Project, which was launched by Turkish Ministry of National Education (MEB) in November 2010.

Determining how individuals perceive technology before they use newly emerging technologies is effective in the use of technology. Technology Acceptance Model (TAM), which is among the most widespread of acceptance models starting from this standpoint, determines the acceptance of technology by addressing users' perceived ease of use, perceived usefulness, attitude towards use and intention of use (Mortenson and Vidgen, 2016)

There are various models and theories related to the diffusion, adoption, acceptance and use of innovations. The theories and models are evaluated specifically in terms of education, supplemented by other convenient elements and included in studies in field of education. The theories and models used in researches carried out on the diffusion, acceptance and adoption of innovation are as follows: (Al-Senaidi, Lin and Poirot, 2009; Martínez-Torres, Marín, García, Vazquez, Oliva and Torres et al 2008; Van Raaij and Schepers, 2008; Usluel, Aşkar and Baş, 2008; Wang, Wu and Lu, 2009)

- Diffusion of Innovation Theory

- Theory of Reasoned Action

- Unified Theory of Acceptance and Use of Technology

- Theory of Planned Behavior

- Technology Acceptance Model

The literature review by Ovčjak, Heričko and Polančič (2015) Technology Acceptance Model (TAM), Theory of Planned Behavior (TPB), Theory of Reasoned Action (TRA), Unified Theory of Acceptance and Use of Technology

\footnotetext{
*This article study was derived from the doctoral dissertation of İsmail Tonbuloğlu.
} 
(UTAUT), and Diffusion of Innovation Theory (DOI) regarding the acceptance of mobile data services covered 80 studies, which most commonly focused on: Technology Acceptance Model (TAM), Theory of Planned Behavior (TPB), Theory of Reasoned Action (TRA), Unified Theory of Acceptance and Use of Technology (UTAUT), and Diffusion of Innovation Theory (DOI). 64 out of the 80 studies reviewed addressed TAM. Distribution of the other models is as follows: TRA (12), UTAUT (10), DFI (8), TPB (6) and others (10). When the factors are reviewed, it is seen that the most commonly addressed factors in the studies include behavioral intention (77), perceived usefulness (61), perceived ease of use (55), subjective norms (32, complexity, social effect, etc.), attitude (24), confidence (24), individual innovativeness (13), and System Quality (5). The results of the study emphasize that the number of studies on mobile technology has increased, and examining acceptance of mobile technology in specialized content will contribute to the literature.

The purpose of the study is to identify opinions of preservice teachers on their acceptance of the use of mobile technologies for teaching purposes. The study seeks to explore the following question:

- What are preservice teachers' opinions regarding the acceptance of the use of mobile technologies for teaching purposes?

The study examined preservice teachers' acceptance of the use of mobile technologies for teaching purposes and their dependence on mobile technologies. It is considered that the study will contribute to the literature in terms of design, use and diffusion of mobile learning and teaching processes of not only students and teachers taking part in FATIH Project but also other individuals in the society.

\section{Methods}

This is a phenomenological study. Cropley (2002) and Creswell (2013) state that a phenomenological study concentrates on the phenomena of which we are aware but do not have in-depth knowledge. The data sources in phenomenological studies are individuals or groups who experience the phenomenon on which the study focuses, and who are capable of expressing such phenomenon (Büyüköztürk, K1lıç-Çakmak, Akgün, Karadeniz and Demirel, 2012). Phenomenological studies are a questioning strategy by means of which the researcher endeavors to define the essence of human experience with regard to a phenomenon explained by participants (Creswell, 2013). Phenomenological studies provide a convenient research base for studies aiming at examining phenomena which are not fully unfamiliar yet are hard to fully comprehend. The data source in phenomenology is individuals or groups who experience the phenomenon on which the study focuses, and who are capable of expressing or reflecting such phenomenon experienced (Creswell, 2008).

\subsection{Study Group}

Semi-structured interviews were held with the individuals selected by criterion sampling method. Observation units in studies may consist of persons, events or objects with certain characteristics. Criterion sampling method includes units (objects, events, etc.) meeting the designated criterion into the sample (Büyüköztürk et al, 2012). Internet use for more than 40 hours a week for purposes other than work and education is described by Young (1998) as "problematic internet use" while Tao, Huang, Wang, Zhang, Zhang and Li (2010) defines that time limit as six hours a day. Whereas, it is indicated in the report by Yeşilay (2015) that two hours of technology use daily is considered healthy. As it was estimated that, in the view of the criteria of technology use in the literature, selecting individuals using technology for 3 hours or longer daily for the study on acceptance of the use of mobile technology would provide more accurate information in terms of the purpose of study, the use of mobile technology for more than three hours was taken as the criterion. In scope of the designated criterion, semi-structured interviews were held with 4 preservice Turkish teachers and 4 preservice Science teachers who use mobile technologies for 3 hours or longer daily.

\subsection{Development of the Data Collection Tool}

By using the interview questions prepared by the researcher in frame of the Technology Acceptance Model, semi-structured interviews were held on acceptance of the use of mobile technologies for teaching purposes. The interview questions were prepared by using the interview questions in the studies performed by Donaldson (2011) and Garfield (2005) and they were edited in frame of the Technology Acceptance Model. The questions prepared were later edited by referring to opinions of 3 subject-area specialists. Following the editing, interviews were held by using the final form of the interview questions.

\subsection{Validity and Reliability}

The evaluative criteria of Lincoln and Guba (1985), which include credibility, authenticity, transferability, dependability and confirmability, were taken into account so as to ensure validity and reliability of the data collected via the semi-structured interview form. It was underlined that ensuring credibility (internal validity) requires in-depth collection and diversification of data, review by specialists and confirmation by interviewees. It was emphasized that a 
detailed description and selection of the study group by purposive sampling is of significance for purpose of ensuring transferability (external validity). It was noted that the data collected must be presented descriptively without comments, multiple studies must be included in the process and the data must be confirmed by different researchers so that consistency (internal reliability) can be achieved. For confirmability (external reliability), it was emphasized that data must be confirmable by an external specialist (Lincoln and Guba, 1985). To achieve credibility in frame of the study, the duration of semi-structured interviews was kept long, in-depth data were collected and the interviewees were asked to confirm transcriptions and sound records of the data collected. To achieve transferability, the study group was determined by purposive sampling method, and the qualitative data were described in detail. To achieve consistency, the data collected were presented by citations, the coding and theme process was repeated by two different researchers and the data obtained were crosschecked. Additionally, opinions of a Computer Education and Instructional Technologies specialist on the qualitative data collected were referred to for purpose of contributing to the confirmability of the study.

\subsection{Research Process}

8 preservice teachers were interviewed in scope of the research. The interviews lasted 18 minutes on average. Transcripts of the eight interviewees had 40 pages in total. Theme and coding processes were performed by two different researchers in frame of the related transcription. Following the coding process, differences in coding were reviewed and the codes and themes created were given their final form.

\section{Findings}

As a result of the analysis on findings of the interview held on basis of the question "What are preservice teachers' opinions regarding the acceptance of the use of mobile technologies for teaching purposes?" , 6 different themes in Table 1 emerged.

Table 1. Themes for Findings of the Interview on Acceptance of the Use of Mobile Technologies for Teaching Purposes

Themes
Perceived Usefulness and Ease of Use
Intention of Use and Attitude Towards Use
Social Effect
Individual Competency
Integration in Educational Environment
Innovation
rms of the "Perceived Usefulness and Ease of Use", Theme

3.1 Findings of the Interview in Terms of the "Perceived Usefulness and Ease of Use" Theme

Interview codes for the "perceived usefulness and ease of use" theme are shown in Table 2.

Table 2. Codes for the "Perceived Usefulness and Ease of Use" Theme

\begin{tabular}{ll}
\hline Theme & Code \\
\hline Perceived Usefulness and Ease of Use & Efficient (2) \\
& Enhances / enriches the lesson (3) \\
& Practical use (2) \\
& Attracts the student / increases attendance (5) \\
& Form of use (1) \\
Concretization (3) & Permanent learning (3) \\
Visualization (3) & Internalization (2) \\
Easy to understand /learn (4) & Contribution to learning (3) \\
Opportunity of out-of-school learning and individual \\
practice (3) \\
Copyright Fees (1) \\
System and service quality (3) \\
Classroom management (5) \\
Easy / fast access to information (5) \\
Storability (1) \\
Information / communication from the first source (1) \\
Student / teacher communication (4) \\
Content (1) \\
\hline
\end{tabular}

As seen in Table 2, the following codes come into prominence under the "perceived usefulness and ease of use" theme in preservice teachers' use of mobile technologies for teaching purposes: easy / fast access to information (5); attracting 
the student / increasing attendance (5); easy to understand /learn (4); Enhances / enriches the lesson (3); concretization (3); permanent learning (3); visualization (3); easy to understand /learn (4); contribution to learning (3); opportunity of out-of-school learning and individual practice (3); system and service quality (3); classroom management (5); easy / fast access to information (5) and student / teacher communication (4).

Preservice teachers often emphasized that the use of mobile technologies for teaching purposes attracts the student and increases student attendance in the teaching environment. With regard to the interview code "attracts the student / increases attendance (5)", several preservice teachers stated their opinions as follows:

“... This will better attract the student's attention and they will participate in class ...” (Turkish, 20, Female)

"As most of the kids are very much into technology, you can adapt, let's say a favorite item, to the classroom. So you sort of integrate them into your class. Their favorite stuff. So it will attract the kids'attention. It will do this in a faster, more colorful way, with plenty of images. At least not boring in their opinion. In this sense, I think it's useful." (Science, 24, Female)

Anything different from classical learning methods can really attract the kids'attention. In the classes that I attend, I observe that students may be distracted. But when there is a technological item in the classroom, they can directly focus on that item. It will attract the student's attention and make it easier for them to concentrate. ...

... Nowadays, all students have their own smartphones already and they can have fast access to information. Asking them to put their phones away is, in a way, is to distract their attention. Actually, we should show them how they can use it for the class. Maybe we can also help students gain a different perspective with other means of technology. In this way, you can join the student's sphere of interest. They don't follow our route but we follow theirs so we take the same road together ...

... For example, in a class that I attended for observation, students were handed out test sheets. While half were trying to solve the questions, the other half were just trying to see their classmates' papers. But if the test had been applied via the app called Kahoot, all students would have been able to see the results of their answers simultaneously and more actively take part in that class." (Science, 22, Female)

“... For example, there is this application called Kahoot. You can prepare ten or twenty questions by using that application ... We as university students experienced a class in which our professor used that application. We enjoyed it so much that I can imagine the kids will love it. We would definitely spend more time using the app if we had more of it..." (Science, 22, Male)

“... It makes students participate in the class. I didn't know that it had so much effect on students who usually don't participate when conventional teaching methods are applied. But what I personally witnessed in the classroom environment is that all of the kids, even the distracted ones sitting in the back of the classroom, actively participated in the class when the teacher turned on the computer via the interactive whiteboard. After a while, the teacher shut down the computer, saying he was bored of it. He is not much into technology as he is an elderly person. The kids immediately reacted, asking to spend more time with the interactive whiteboard. ... All students participate in the class. It's so much fun ..." (Science, 22, Male)

Preservice teachers reported that the use of mobile technologies for teaching purposes helps students easily understand/ learn and contributes to their learning. With regard to the interview codes "easy to understand /learn (4)" and "contribution to learning (3)", opinions of preservice teachers are as follows:

“... Let's consider a listening training class, for example. ..

... I think (mobile technologies) can be more useful in a listening training. I mean, it can help students understand the subject more easily" (Turkish, 21, Female)

“... A conventional teacher usually just lectures and leaves. Students are expected to memorize the topics lectured. Mobile technologies are out of those conventional teaching methods, in fact you can easily learn them. They are already our practical instruments. They can bring students to the conclusion that anyone can learn them, and I think they can show them that it is not difficult to acquire knowledge..." (Science, 22, Female)

“...they contribute to the learning of students...”(Turkish, 21, Female)

"... I want the kids to love my class. I kind of want to speed up the course a little bit. I want to make greater contribution to the achievements which we are not capable of making with the entire population of the class..." (Science, 24, Female)

Preservice teachers reported that the use of mobile technologies for teaching purposes helped students concretize what they learn and contributed to permanent learning, visualization and access to knowledge as well as providing 
opportunities for out-of-school learning and individual learning. With regard to the interview codes "concretization (3)", "permanent learning (3)", "visualization (3)" and "opportunity of out-of-school learning and individual practice (3)", opinions of preservice teachers are as follows:

“...It might help better concretize the topic. After all, Turkish is a rather abstract course. Or, to put it another way, improving language skills is not a tangible thing. It's not something like analyzing the DNA structure or model in Science class. This is something rather cognitive, we use less of the psychomotor skills. Making the topic more concrete. Making it as concrete as we can will be helpful for us..." (Turkish, 21, Female)

".. When the student sees it in 3D form, I think all that information begins to make sense...

... There is this one thing: we as humans experience learning from simple to complicated and from concrete to abstract. We have a sequence of learning. People may be puzzled when we try to teach them an abstract concept at the very beginning. If we can make a concept more concrete and tangible, we will learn that particular knowledge more permanently. So that permanent understanding will be achieved. Mechanical learning process will be abandoned..." (Turkish, 21, Female)

“...since biology is too hard to comprehend and rather based on memorization, it can be used more often when teaching biology. Students will not forget the information if it's based on a visual material" (Science, 22, Female)

"...With the increase in the difficulty level of the subject you can teach, the process will become harder. However, technology can help you teach the kids that subject within a shorter time. It will ensure more permanent learning. It will attract the kid's attention to the class...

... As most of the kids are very much into technology, you can adapt, let's say a favorite item, to the classroom. So you sort of integrate them into your class. Their favorite stuff. So it will attract the kids'attention. It will do this in a faster, more colorful way, with plenty of images. At least not boring in their opinion. In this sense, I think it's useful..." (Science, 24, Female)

"Students who cannot afford books, for example." There are lots of websites on the Internet. They can have a look at online lectures." (Turkish, 20, Male)

Preservice teachers reported that the use of mobile technologies for teaching purposes is practical and efficient element which enhances and enriches the lesson. With regard to the interview codes "practical use (2)", "efficient (2)" and "enhances / enriches the lesson (3)" and "easy / fast access to information (5)", preservice teachers stated their opinions as follows:

“... Whenever I come across an interesting topic among educational speeches on TED Talks I view that speech... I use my phone for this purpose. Smartphones provide great advantage especially when you're on the road. They are practical, easy to use. Even if we experience problems with charging the phone from time to time, smartphones still offer great advantage during transportation.

...They make life easier as they become more practical." (Science, 24, Female)

“... They are practical, very easy to use. You need no extra skills to use them. It already has what you need so you can use it..." (Science, 22, Female)

“... Once we organized a workshop in which we designed a material. We created a story there, for example. We also recorded sounds for our story. We supported it with images in the background. From that point on, any topic could be chosen. I made a story out of a lecture on punctuation marks. It was so productive. For me it was a pleasant work." (Turkish, 21, Female)

“... The most interesting aspect is the 3D. We analyzed a related application. Seeing three-dimensional forms of organs of the human body, for example, is a unique experience. It helped me gain a brand new perspective. Considering the achievement I made, I can imagine that it would be totally useful for the student... We learn the subject solely as a concrete topic. We have those organs in our body. It is hard to visualize when we learn them as a subject. But when the student physically sees it in $3 D$ form, I think all that information will begin to make sense ... (Science, 22, Female)

"Access to information is easier and faster... We can have easier access to many things by using smartphones and the internet" (Turkish, 21, Male)

"They cover all areas of our lives. They can function more effectively. We have them in our hands, they are easily available..." (Turkish, 20, Female)

"They are faster and more accessible. They can enable you to have instant access to anything. I think that using mobile technologies in teaching saves quite much time and is much more practical." (Science, 22, Female) 
"We can have faster access to information. When students are given an assignment or when there is a meeting, for example, the entire classroom can acquire that information instantly...

... Here we have a library, too, but we don't have much time to spend going to the library, or to be more honest, we usually neglect using the library. Ever since the mobile technology came into our lives, access to information has been easy. So I choose the easy and fast way to have access to information. Everyone can acquire the information simultaneously. The information can be collectively interpreted" (Turkish, 20, Male)

Preservice teachers indicated that the use of mobile technologies for teaching purposes is influential in classroom management and student- teacher communication. With regard to the interview codes "classroom management (5)", and "student / teacher communication (4)", preservice teachers stated their opinions as follows:

“... As it attract the kids' attention, I expect them to be quiet and patient. If I get a positive result from that practice, which I think I definitely will... As they will see visuals of it, be surprised and give reactions. I anticipate that it will help me in classroom management...” (Science, 22, Female)

“...Anything different from classical learning methods can really attract the kids' attention. In the classes that I attend, I observe that students may be distracted. But when there is a technological item in the classroom, they can directly focus on that item. It will attract the student's attention and make it easier for them to concentrate... (Science, 22, Female)

"But there is one thing: if the teacher loses the control of it, it might be harmful. The teacher may channel it to a positive purpose by selecting problematic students in terms of classroom management to give them tasks like using the interactive whiteboard.

If teachers experience difficulty controlling the class in their third or fourth use of the interactive whiteboard, Then they will feel reluctant to use it again, thinking that they can't maintain the order of the classroom. I would feel that way if I had the same experience..." (Science, 22, Male)

"It prevents misunderstandings in the process, any communication gap is avoided. No misconception is experienced as I directly use it for communication. To put it in other words, communication is easier as there are not many individuals intervening in the process. It contributes much more to face-to-face learning..." (Turkish, 21, Male)

"It attracts the kids' attention to the class. So students form a stronger bond with the teacher. They feel that they like the lesson. In this sense, I think it's highly useful...” (Science, 24, Female)

With regard to the interview codes "form of use (1)", "internalization (2)", "copyright fees (1)", "system and service quality (3)", "storability (1)", "information / communication from the first source (1)" and "content (1)" in the use of mobile technologies for teaching purposes, several preservice teachers stated their opinions as follows:

"..Actually I can use all of the mobile technologies in the class. What matters is to know how to adapt them to the class. Apart from that, all are convenient for use, including smartphones, tablets, and mp3 players. All can be useful..." (Turkish, 21, Female)

"When I am lectured on a subject at the beginning, I feel too much difficulty making sense of all that information given. To internalize the information to comprehend it more easily, I would be willing to use mobile technology in my class...” (Turkish, 21, Female)

"...Maybe I can make use of the apps, which are usually free, but they charge for apps after a certain extent." (Science, 22, Female)

"System and service quality should, of course, be high. All features should be satisfactory, even including Internet access, although Internet speed is the least significant detail. All features should be of high quality to ensure accessibility. They should provide easier and faster access in terms of learning - teaching process.

... Otherwise the lesson will be interrupted. For example, I will connect it to a system if I take it as basis for my class. Any failure in the system will interrupt my class and cause problems. (Science, 24, Female)

".... Its speed is very important. If the backbone of the Internet is not deployed using fiber optic cable, it will have a very low speed and it's a problem. It makes you spend the whole time to have access to the Internet”" (Turkish, 20, Male)

"It offers storage of information. Let's say, for example, I learned or did something online. I find it useful because I will have access to that thing and be able to repeat it for as many times as I can." (Turkish, 21, Male)

"It offers an advantage in terms of communication. Regardless of between you and your contact, you can still build communication with that contact and have instant access to the information from the primary source. Let's 
assume that I'm looking for an answer to a question related to an activity and that I know a person who performed that specific activity and whom I believe to know that answer, I can use my smartphone to send an e-mail or make a phone call to that person. So I can have access to the answer.

Let's assume that I have been qualified as a teacher. I give an assignment to the students and expect them to study on the subject of assignment. I can say: "Here are the questions you will answer"... Students can e-mail me or contact me via my social media accounts and directly ask their questions to me" (Turkish, 21, Male)

"For instance, there are problems in having access to the right source on the Internet. As the Internet contains so much false and unconfirmed information, I don't think it's a healthy platform.

....I think that the sources of information on the Internet are ambiguous. I don't think that they are fully accurate" (Turkish, 20, Male)

3.2 Findings of the Interview on the "Attitude Towards Use and Intention of Use" Theme

Interview codes for the "attitude towards use and intention of use" theme are shown in Table 3.

Table 3. Codes for the "Attitude Towards Use and Intention of Use" Theme

\begin{tabular}{ll}
\hline Theme & Code \\
\hline Attitude Towards Use and Intention of Use & Student - interest/attention/ motivation (7) \\
& Examples / areas of use (8) \\
& Necessity (5) \\
Overuse (4) & Enriching / enhancing the lesson (3) \\
& Choosing the easy way (2) \\
& Opportunity of practice / experiment/ simulation (1) \\
& Knowing the examples (1) \\
& Class integration (1) \\
& Sparing time to prepare for the class (1) \\
& Student reaction (1) \\
\hline
\end{tabular}

As seen in Table 3, the following codes come into prominence under the "attitude towards use and intention of use" theme in preservice teachers' use of mobile technologies for teaching purposes: interest/attention/ motivation (7); examples / areas of use (8); necessity (5); overuse (4); and enriching / enhancing the lesson (3).

With regard to the aspects influencing attitude and intention of preservice teachers towards the use of mobile technologies, the student's interest, attention and motivation are primarily addressed in findings of the interview. Additionally, preservice teachers often emphasized their opinion that awareness of the examples of use and technology have recently been taken into consideration as a requirement. With regard to the interview codes "student interest/attention/ motivation (7)", "examples / areas of use (8)" and "necessity (5)", some of the opinions reported by preservice teachers are as follows:

"Kids these days are fond of technology. I would like to use technology because it attracts the attention of students." (Turkish, 21, Male)

"For example, technology is more appealing for kids...

Students are better motivated as they are interested in technology and they use (mobile technologies). They are motivated when they see a computer or a tablet. Therefore I would use it..." (Turkish, 20, Female)

Anything different from classical learning methods can really attract the kids'attention. In the classes that I attend, I observe that students may be distracted. But when there is a technological item in the classroom, they can directly focus on that item. It will attract the student's attention and make it easier for them to concentrate." (Science, 22, Female)

"As I said before, I witnessed that technology motivates students to take active part in the class and have fun...Active participation of students and the entertaining aspect of technology would make me prefer using it...

And I would also use it to make the class interesting for students who are reluctant to participate. (Science, 22, Male)

"There was a program called Aurasma. We used it on the board. We displayed on the board the photographs of scientists who are introduced in related units of the curriculum. When a student runs Aurasma in front of such photograph, it triggers videos about the scientist in that photograph ...

... I have lately discovered that A new program called 4D is now available, which means 4 dimensional. I discovered it on websites like Facebook... I am registered on websites the members of which consist of science 
teachers. I observed the use of that technology on those websites, for example. A four dimensional zoo. The teacher tells students that they will go to the zoo. And then, the teacher shows them the animals on 4D program. The technology might be used in this way." (Science, 22, Female)

"Technology employs images so this can be primarily used. Videos can be used. Online applications can be used." (Turkish, 20, Female)

"For example, there is this application called Kahoot. ..

We as university students experienced a class in which our professor used that application. We enjoyed it so much that I can imagine the kids will love it. We would definitely spend more time using the app if we had more of it...

... I'm planning to use Kahoot...

... There is a crossword puzzle which I learned to do. I can do it online” (Science, 22, Male)

"I can use it to teach a subject, for example, as I am a Turkish teacher. I can show my colleagues or students an excerpt from a video, to draw attention to the misusel degeneration of an expression.

I use my computer to clip a short excerpt showing my example from a longer video, download the excerpt to a flash memory and take any technological device which I need to use at school to play the excerpt, or if not available, I take my own computer to school. Then I play the video by using the slide machine or on my computer (Turkish, 20, Male)

“... I know that it is the primary means which I definitely have to use. This is what the age of technology requires. ...

I mean, I would definitely use it." (Turkish, 21, Female)

"I want to use mobile technologies for teaching purposes because the future will be built on basis of technology, so this is what needs to be done. As I told you, it is already great to see that expression on the faces of students'. There are even times when we wish we had been provided with similar opportunities. I want to learn how to use that technology because I really appreciate it. I think students should no more be deprived of such opportunities" (Science, 22, Female)

"This is something indispensable in today's world.

Technology is now a part of our lives, that is, it covers every field of life, so I would like to make use of its educational advantages." (Turkish, 20, Female)

"Technology is necessary to abandon conventional teaching and lecturing. It is crucial to keep up with the times. (Science, 22, Male)

With regard to the aspects influencing attitude and intention of preservice teachers towards the use of mobile technologies, enriching and enhancing the lesson is primarily addressed. Additionally, preservice teachers emphasized in the the findings of the interview that the use of mobile technologies for teaching purposes may cause students to choose the easy way or overuse technology, and this may affect their attitude towards use and intention of use. With regard to the interview codes "enriching / enhancing the lesson (3)", "overuse (4)" and "choosing the easy way (2)", opinions of preservice teachers are as follows:

"If you can use it adequately and efficiently, they really offer lots of rich content to discover, and I would like to use them in my classes." (Turkish, 21, Female)

"Because I want the kids to love my class. I kind of want to speed up the course a little bit. I want to make greater contribution to the achievements which we are not capable of making with the entire population of the class." (Science, 24, Female)

"... I think simulations, 3Ds will become more widespread. Because they are more practical in terms of both the learner and the teacher and they are time saving. Indeed, they ensure that both parties achieve their learning and teaching purposes without getting bored. In other words, it would be preferable to use the available technology a little bit more without making things complicated. It would be easier. I think using mobile devices is the primary choice for now if we want to go beyond conventional methods" (Science, 22, Female)

"... it will be bad if mobile technology is overused. Because we don't do everything on the internet. We don't do everything with mobile technology. It would be a problem if the student always wanted to use the computer or smartphone and preferred mainly the mobile technology for communication even when not necessary...

... I don't think it makes any sense when we spend the most of our time on the Internet. We should use the technology only if we can't have access to information when we want to. On the other hand, it might somewhat 
make kids avoid hard work." (Turkish, 21, Male)

"It's like you can't live your life to the fullest when you use it too frequently. Like you isolate yourself from real life...

But I think it won't cause a problem when it is used with control." (Turkish, 20, Female)

"After all, there is the term coined as Technology Addiction. When the frequency of use of technology increases, this might give the impression that the teacher is trying to reduce workload, taking the easy way out ...

... A good balance must be set. To be honest, I think that teachers should not use technology too often. Some content may be worth showing and some not. If the teacher is able to explain the subject in different ways, I think they should provide the information themselves rather than relying on technology, for the fact that technology is already interfering more and more into our lives each day. I think overuse makes no sense at all." (Science, 24, Female)

"Students may lose interest if technology is overused" (Science, 22, Female)

The findings of interview included the following aspects which influence the attitude and intention of preservice teachers towards the use of mobile technology for teaching purposes: opportunity of practice, examples, integration, student reaction, course preparation. With regard to the interview codes "Opportunity of practice / experiment/ simulation (1)", "knowing the examples (1)", "class integration (1)", "sparing time to prepare for the class (1)", "student reaction (1)", preservice teachers stated their opinions as follows:

“... As it's not possible to do every experiment in every environment. They can't be done with every child as well. I think that helping the child do the experiment by visual observation or simulation will somewhat influence the content ...

... I mean, there are experiments which are difficult to do ... there are large scale experiments...

... Surely, the achievement is certain but there are circumstances in which we may have trouble depending on the child's profile..

... There are experiments which may be harmful. The amount of substances, etc. may even cause disruption in the course of teaching. They may cause physical harm to the child, as well. There are many such cases that we read in the news. That's why it (using mobile technology for teaching purposes) is beneficial in material and moral aspects. " (Science, 24, Female)

"First of all, I need to know such program. I need to find out if there is such program. If I know it, I can use it in my class." (Turkish, 21, Female)

3.3 Findings of the Interview on the "Social Effect" Theme

Interview codes for the "social effect" theme are shown in Table 44.

Table 4. Codes for the "Social Effect" Theme

\begin{tabular}{lll}
\hline Theme & Category & Code \\
\hline Social Effect & Peer Effect & Usage by Peer / Colleague (8) \\
& Teacher Effect & Use of mobile technology in class for teaching purposes (7) \\
& & Inefficient use of mobile technology (4) \\
& Use of mobile technologies with effective methods and \\
& techniques for teaching purposes (1) \\
& Routine frequent use of mobile technologies for teaching \\
& purposes (1) \\
& Digital Social Environment & Social Media (2) \\
& Other digital environments (3) \\
& Workshop/ seminar (4) \\
& Other social factors (1) \\
\hline
\end{tabular}

As is seen in Table 4, social effect is reflected on the use of mobile technologies by preservice teachers for teaching purposes. Social effect primarily includes peer effect, teacher effect, and the effect of digital social environment and other social environment.

With regard to the interview code "usage by peer / colleague (8)" in the use of mobile technologies by preservice teachers for teaching purposes, several preservice teachers stated their opinions as follows:

“...I don't like technology but I can't remain unresponsive to technological developments. This is what our age requires. Definitely, my objective is to avail myself of them. I will surely try to adopt them and make use of them. 
Maybe I will be more interested in technology as I see peers and teachers using it. (Turkish, 21, Female)

"... The use of technology by my friends and colleagues would create a (positive) effect, as I would have someone to refer to when I need to learn something. Honestly, we are usually concerned about its social aspect, as I mentioned before, and my social circle using the technology has a positive effect on my efforts to eliminate my concerns.” (Science, 22, Female)

“...our social environment always has a positive / negative effect. Mobile technology can be motivating, which is a positive effect. On the other hand, it may cause a negative effect, leading to comments like "why you are spending so much effort on it?". You might feel discouraged when you receive comments like "This isn't really necessary. You could teach this subject by lecturing. You could use the conventional lecture method". Or you may not feel encouraged. You know, there are times when you can't find a way out. You just expect to have some assistance and be encouraged by others with suggestions like "it would be better if you did it this way". But if you receive a negative comment, like "you didn't really need to do that", you may just give up. You may decide not to go on with it." (Science, 22, Female) “... It would be motivating. I wouldn't want to lag behind them (my colleagues). I would be motivated by their use of technology. (Science, 22, Male)

"..It would have an effect if I had friends (using it). If they said, for example, "I am using this one and it is useful”, then I would ask them how it works." (Turkish, 20, Male)

The use of mobile technologies in teaching process by preservice teachers for teaching purposes is seen to have positive and negative effects on students. With regard to the interview codes "use of mobile technology in class for teaching purposes (7)", "inefficient use of mobile technology (4)", "use of mobile technologies with effective methods and techniques for teaching purposes (1)" and "routine frequent use of mobile technologies for teaching purposes (1)" under the social effect on teachers, several preservice teachers stated their opinions as follows:

"To tell the truth, we don't have any conversation like "how can we adapt such mobile technology to our class?" or "how can we use it?". Our discussions are often related to reading and writing. Honestly, it may be partly my fault. Because I did not refer to my instructors. I didn't ask them how we can use mobile technology. They would probably tell me if I asked them." (Turkish, 21, Female)

"(My instructors using it in class) ... would have a positive effect. After all, you will be learning technology. You will be learning new things. I would have a better focus, I would become more interested. Maybe I would download that app, too. I would use it, too. (Turkish, 20, Female)

"If I had colleagues or instructors around me using it, I would certainly want to have a look at it. ... My acquaintance with them (would influence my eagerness to use the technology). If I have trust in them in educational terms, and if they have personally used the technology, I would just have a go at it" (Science, 24, Female)

“... One of our instructors has a major influence on our awareness on the subject. Thanks to our instructor (we learned a lot on technology). (S)he was the one who taught us all these (educational) programs and so on. ... This has a positive effect on us in educational terms. I didn't even know that there were so many programs. It seems that there are lots of them. "... We can practically and easily use them. There is no need for extra skills to use them. They are already available, you can use them.” (Science, 22, Female)

"Throughout part of my middle school years and most of my high school years, I attended classes in which my teachers lectured by showing slides on a projector. And I've never liked it. I don't want to like it. And I think this method is wrong. It caused me to feel very reluctant to listen to their lecture. " (Turkish, 21, Female)

"I don't like it when it is overused, for example. But there are some teachers who only read the slide. I personally make use of technology. But then, lecturing will no more be useful. Wrong use of technology will lead to the end of lecturing. And eventually, it will make me lose my interest in slides. It needs to be used consciously. " (Turkish, 21, Male)

"There is this one point. There must be a difference between a teacher and a student. In terms of educational methods and techniques used. When you project a slide on the whiteboard, the student can read the slide, too. The teacher must create a difference at this point ... (It's not useful) to keep doing the same thing over and over again, to avoid enriching it (the process), to always use the available material with the same method, to ignore other different features of that material." (Turkish, 21, Female)

Digital environment and other environmental factors are observed to have an effect in respect of the use of mobile technologies by preservice teachers for teaching purposes. With regard to the interview codes "social media (2)", "other digital environments (3)", "workshop/ seminar (4)" and "other social factors (1)" under the digital and other social 
environment, several preservice teachers stated their opinions as follows:

“... I have lately discovered that a new program called $4 D$ is now available, which means 4 dimensional. I discovered it on websites like Facebook. I am registered on websites the members of which consist of science teachers. I observed the use of that technology on those websites, for example. A four dimensional zoo. The teacher tells students that they will go to the zoo. And then, the teacher shows them the animals on 4D program. Maybe the technology might be used in this way..." Whenever I come across (a new application) on social media, I immediately have a look at it.

.... I read the comments about the app, and the reviews stating how users applied it. By doing so, I have overcome the feeling that we call fear or incompetency." (Science, 22, Female)

"You know, there is an android application called Google play, I often stumble across apps in educational category, such as, for example, apps for Turkish class. I read the reviews on the app. They write things like "I recommend you to download it, it is useful, etc." or "I don't recommend you to download it". I download the app and then try it, and go on with it if I find it useful. I remove the app if it doesn't meet my needs." (Turkish, 21, Male)

There is a material design workshop. I attend that workshop in addition to my education at the university. We have our works there. We design and discover materials. I think I would apply those works in my own class. I mean, I feel motivated by those works." (Turkish, 21, Female)

3.4 Findings of the Interview on the "Individual Competencies" Theme

Interview codes for the "individual competency" theme are shown in Table 5.

Table 5. Codes for the "Individual Competencies" Theme

\begin{tabular}{lll}
\hline Theme & Category & Code \\
\hline Individual Competency & Technical Competency & Technical Knowledge (4) \\
& & Technical Concern / Fear (3) \\
& Past Use of Technology (1) \\
& Professional Competency & Form of Use (1) \\
& Knowing the Examples (1) \\
& Assistance & Technical Support (6) \\
& Educational Support (5) \\
& Self-reliance & Self-confidence (5) \\
\hline
\end{tabular}

As is seen in Table 5 , individual competencies are reflected on the use of mobile technologies by preservice teachers for teaching purposes. Individual competencies primarily include the effects of technical competency, professional competency, support and self- reliance. With regard to the interview codes "technical knowledge (4)", "technical concern / fear (3)" and "past use of technology (1)" regarding the use of mobile technologies by preservice teachers for teaching purposes, several preservice teachers stated their opinions as follows:

"I need to learn more. ... I need to learn more about technical programs/ instruments. Then I can definitely do it. It will definitely yield results." (Turkish, 21, Female)

"I may have difficulty in technical parts. I may have difficulty due to my lack of knowledge. After all, we don't completely know how tablets or computers work..." (Turkish, 20, Female)

"To me, computers are like a black box. I try to spend less time using my smart phone or when I use it, I try to limit my use to instructional videos. Apart from that, I really avoid using it." (Turkish, 21, Female)

"...At times it may be hard to access, you may lack knowledge. You have to seek for it. Users are usually hesitant at first, as the sources are in English language. You tell yourself to avoid it because it is a source in English. You keep thinking how it will going to happen or what if you do something wrong. ... Actually, I don't have much concern in technical terms. I'm not bad at technology. Figuring out applications, for example. But there is still this feeling which is like timidness. Probably it has to do with plumbing the depths of it... It brings to mind questions like "what if I fail to do it (not in technical terms)", "what if the system brings something totally new to me and what if I have trouble with it?" "What kind of problems will I experience?" We feel worried partly because we can't foresee the process." (Science, 22, Female)

"If I fail, I will lose my interest in it, as I said before." (Science, 22, Male)

"I don't feel much competent. Because I don't know about it. I feel incompetent because I come from a small town where sources were limited. Source of communication, for example. There were no courses. Public education centers did not provide technology courses. My school did not organize such a course. I encountered technological environments more often after I started my university education." (Turkish, 21, Male) 
Preservice teachers' needs for support in their use of mobile technologies are addressed in the findings of the interview. With regard to the interview codes "technical support (6)" and "educational support (5)", opinions of preservice teachers are as follows:

"At first I always need someone for help. Then I can do it on my own. I just doubt that I can do it myself. I definitely need other's help." (Turkish, 21, Female)

“...Having a colleague to support me would have a positive effect on me. Let's say, for example, that I will make a presentation on the digestive system. I can make that presentation by using this software. And if I can have some technical assistance when I have trouble using the software, it would be a good contribution." (Science, 22, Female)

"I would use it more often if I had assistance. For instance, let's say that I have no idea about the technology. I will need someone to teach me so I will be able to teach my students about it. ... I would prefer someone to help me in technical and practical matters." (Turkish, 21, Male)

"I don't think I can't use it, but I feel incompetent. Every technological instrument has different principles of operation, sometimes you can't do it simply by having a manual and reading the instructions. Definitely, technical support would be necessary at that point. I don't know whether it would be a contact person in the district or a service accessible via phone, but it would be certainly necessary." (Science, 24, Female)

"It would be nice if we had technical support. We could solve any problem arising during the class in collaboration with the technical expert. Then I would keep on using it. Or let's say, for example, that the class is disrupted. Then I would never use that technology in the next class. (Turkish, 20, Male)

“... Technology has always been evolving. A new application is emerging every day. I think it would be useful to have some external assistance... In terms of integration, there is need for some guide at the beginning, but I think the rest is the user's business." (Science, 24, Female)

I wish there was educational support available. Most of us know all of the subjects but we have problems when it comes to practice. What's important is to create a new system and to learn by experiment. We lack this skill. This is what we are taught but we don't learn it that way. (Science, 22, Male)

Preservice teachers' self- reliance effect on their use of mobile technologies is addressed in the findings of the interview. With regard to the interview code "self- confidence (5)", opinions of preservice teachers are as follows:

"If I conduct a research and enter into the process, I will surely get results." (Turkish, 21, Female)

"...As I already said, an application in foreign language makes me worry about not being capable of using it.

... I think that there are more problems in individual competency. Because we behave rather timidly. As our basic education is not based on such type of approach, we don't receive that education at elementary school, middle school, high school and university. That's why we personally feel incompetent. (Science, 22, Female)

"I don't feel much competent. But honestly, I don't think I'm totally incompetent, either. I have more or less interest in the subject, too. It's nice to be able to use it, but I don't think I'm very good at it even if I'm not totally incompetent. (Science, 22, Female)

"It takes time to learn and adapt at first... But will not take too long."(Turkish, 20, Male)

3.5 Findings of the Interview for the "Integration in Educational Environment" Theme

Interview codes for the "integration in educational environment" theme are shown in Table 6.

Table 6. Codes for the "Integration in Educational Environment" Theme

\begin{tabular}{lll}
\hline Theme & Category & Code \\
\hline Integration & inUniversity & Use of mobile technology in class for teaching purposes (7) \\
Educational & & Examples of teaching / activity / practice (5) \\
Environment & University department (2) \\
& \multirow{2}{*}{ In-Service Training } & Adaptation to class (4) \\
& & Examples of activity (3) \\
& In-service training perception (2) \\
& Teaching methods and techniques (1) \\
\hline
\end{tabular}

As is seen in Table 6, preservice teachers addressed the integration of mobile technologies into educational environment under the categories of university and in-service training. It was noted that the use of mobile technologies for teaching purposes is introduced in class during university education, and it is integrated into other courses through activities and practices. Moreover, preservice teachers pointed out to the effects of the availability of a department at the university, 
aiming at integration of the use of mobile technologies for teaching purposes. With regard to the interview codes "use of mobile technology in class for teaching purposes (7)", "examples of teaching / activity / practice (5)", "university department (2)" in scope of the integration of mobile technologies in the educational environment for teaching purposes, several preservice teachers stated their opinions as follows:

"Maybe it would be more helpful if there was a practice related to mobile teaching at the faculty of education. We have a tutor there, for example, who shows us some of these practices but we never implement them. We were provided with this information only in one lesson... Our tutor showed us the software but we neither performed any study nor did any practice on it. So I already forgot what we learned...

The use of technology would be more efficient at the university and we are more eager to learn this kind of things. Therefore, I would prefer using it at the university. (Science, 22, Female)

"Of course, I would like to receive a course on MT. I'm sure there are many applications that I am unaware of. I don't think as well that I know too much ... I would want to learn it before I start my career. So, it will trigger my curiosity, and I think I will more closely follow the technology in my career." (Science, 24, Female)

"I mean, if we think the future is important, then we need to make plans for the future. Currently, the use of mobile technologies in education has been considerably increasing and they offer advantages, as we said. We had computer class but it didn't involve technologies too much. We firstly need to be taught software in applied courses at the university. The first software that we learned through practice in the material course have still been in our mind. The following courses were not that good as they were not applied courses. I think that such software should be taught at the university and their versions adapted to education should be introduced during in-service training. (Science, 22, Female)

"For integration to the teaching process, I would like to receive training on the mobile technology during this current process of education. Such training should not only be theoretically but also practically given. I lack experience. I would like to have (a class on) it. (Science, 22, Male)

"Applications can be introduced. Exemplary classes can be held to show how applications can be used. Maybe students can be asked to make presentations again on such applications and it can be reviewed which applications are used by students and in which branches they are used. I think this would directly contribute to the teaching process of teachers. So they would later have a chance to use them and more strongly adopt them. (Science, 22, Female)

"Well, I would like to have, for example.... Depending on the branch, for example... Let's say that abstract concepts are hard to explain. I would like to see, for example, how I will explain abstract concepts by using such technologies. I would like to have examples which are directly related to our class." (Turkish, 21, Male)

"I think there are plenty of applications. Except those that I've heard. I mean, I would definitely want to receive a training on it. I would prefer the instructor to show how to apply them to different branches. At least they should guide us. It would be still okay if they did not teach us all details because we need some productivity and how far can we go only with the things that we know? ... It would open up my horizons. I would better know what to use and how to use it in my courses with children. I think that learning mobile technology would develop my perceptions in different circumstances... I should have training on the use of mobile technologies. We need to comprehend its relation with teaching methods and have such training in connection with the teaching in the classroom." (Science, 24, Female)

"I think, if we learned such technologies in terms of their use by teachers in the first two years of our education, it would not be an intimidating course. Finally, learning them in a systematic way would help us gain confidence about it and encourage us to put them into practice. ... For example, we contemplate on teaching or use of mobile technologies. But after a certain point, we feel that we don't know anything. How are they used? What will happen when they are used? If there was a unit or desk at the university, we could now go ask them. We could improve our knowledge of them. A unit can be launched for this purpose at schools. Like, for example, laboratory teaching and theoretical teaching are different sessions at private schools. Like an IT workshop. When teachers can't find a solution to that matter, it means it's over. We have this current situation because it is not possible for everyone to know everything. Otherwise, we could immediately bring a solution." (Science, 22, Female)

With regard to the interview codes "adaptation to class during in-service training (4)", "examples of activity (3)", "in-service training perception (2)" and "teaching methods and techniques (1)" in scope of the integration of mobile technologies in the educational environment for teaching purposes, several preservice teachers stated their opinions as follows:

"If we are taught how we can adapt them to various topics, and I can study on it, I would definitely like to have 
such training." (Turkish, 21, Female)

"Of course, I'd like to have it both as a preservice teacher and a teacher, as both processes are not independent of each other. You complete the preservice teaching period and become qualified as a teacher. And technology has always been evolving. A new application is emerging every day. I think it would be helpful to have some external assistance. Surely, it would make a difference. Hmm. When you start your career, of course you will be more experienced. You will get to know children better. You can analyze more precisely what you can give them and how. Honestly, I would prefer having such training immediately after our theoretical training. If I had to make such a choice... I think the training given to qualified teachers would be more useful. You will have the privilege to have enough awareness to add new knowledge to the subjects of training you've received (Science, 24, Female)

"We can have trainings on applications which can be used in teaching. We can be instructed on how activities will be used, and how we can combine activities with mobile technologies." (Turkish, 21, Female)

"A variety of applications can be made available during in-service trainings. For example, there were websites to create crosswords. We learned them. We can be instructed on how to use them, or, as we noted earlier, flash cards can be taught." (Science, 22, Female)

"I would want to see the popular ones. I would like to see unique and new things. To adapt myself to developments. I would like to have concrete examples aimed at practice. When I become a qualified teacher, I would want to possess that knowledge only to keep up with my colleagues. The practice for qualified teachers can be made available in form of seminars, congresses." (Science, 22, Male)

"I would try, as far as I could, to develop new teaching methods and techniques which would enrich my teaching. It doesn't matter if I do or don't feel eager to take part of it, but it would be better if I could become helpful for my students. So I would take part in it for the sake of my students." (Turkish, 21, Female)

3.6 Findings of the Interview in terms of the "Innovation" Theme

Interview codes for the "Innovation" theme are shown in Table 7.

Table 7. Codes for the "Innovation" Theme

\begin{tabular}{lll}
\hline Theme & Category & Code \\
\hline Innovation & Research & Study on course contents (1) \\
& Awareness on Innovation & Follow-up of innovations (8) \\
& & Educational practices (6)
\end{tabular}

As is seen in Table 7, preservice teachers addressed positive and negative effects under the categories "study on innovation" and "awareness on innovations" in the use of mobile technologies for teaching purposes. With regard to the interview codes "study on course contents (1)", "follow-up of innovations (8)" and "educational practices (6)" in the use of mobile technologies by preservice teachers for teaching purposes, several preservice teachers stated their opinions as follows:

"The idea of how children can understand better. My desire to improve my teaching methods and techniques might increase my enthusiasm. Or, let's say, for example, I come across an MT device or material somewhere. I could feel enthusiastic to use it by myself" (Turkish, 21, Female)

"I am trying (to follow the latest developments). I don't claim that I can definitely follow all developments. But as I said before, whenever I come across an application on social media, I immediately have a look at it. However, I don't regularly check if there are any new applications launched." (Science, 22, Female)

"I can say that I have lately started following such developments. I wasn't much aware of them until today. I mean each application that I learn about, which I guess are newly becoming popular... That's why they started to attract our attention so much. Now I'm trying to follow those developments" (Science, 22, Female)

".. Most teachers are unaware of them. There are teachers who are incapable of turning on an interactive whiteboard, let alone using applications. I would pay effort to keep up with the times. New students are coming and they all keep up with the times. So I would make a difference between me and other teachers. And I would close the gap between me and students. As today's students live in the information age, even a toddler can have very good computer skills." (Science, 22, Male)

"I think the applications will be further developed. They will be launched in branches of an existing application. Like Facebook, for example, which was followed by Twitter and other social media. Likewise, I think different branches may grow out of the same application. ... I saw that 4D application, which I told about, I like it quite a lot. Now I'm planning to apply it, for example. I read the comments about the application, and the reviews stating how users applied it. By doing so, I have overcome the feeling that we call fear or incompetency." (Science, 22, 


\begin{abstract}
Female)
"I'm not self-motivated to search for applications. But when I hear about an application during conversations with friends... When they tell me like "there is an application which can do this and that, then I will check it out. I'm not into directly searching for up-to-date applications. (Turkish, 21, Male)

"I once read about an application in TÜBITAK science journal. It was a different application and I liked it. You download the app. It gives you a flower which needs watering. The rule is to drink water before you water the flower. This application motivate children to drink water in their daily lives. When you get an alarm sound or a ring tone, you will remember that you should drink water. I liked that application. (Science, 24, Female)

"I think simulations, 3Ds will become more widespread. Because they are more practical in terms of both the learner and the teacher and they are time saving. Indeed, they ensure that both parties achieve their learning and teaching purposes without getting bored. In other words, it would be preferable to use the available technology a little bit more without making things complicated. It would be easier. I think using mobile devices is the primary choice for now if we want to go beyond conventional methods. ... There are coding games, for example. I think they are quite new. It is a huge sector. I searched websites, and saw that you can log into one of those websites simply as a student and develop a game with basic programming. Until now, I didn't know that coding a game was possible. (Science, 22, Female)
\end{abstract}

\title{
4. Conclusion
}

The opinions of the preservice teachers on their acceptance of the use of mobile technologies for teaching purposes address the following themes: "Perceived Usefulness and Ease of Use", "Intention of Use and Attitude Towards Use", "Social Effect", "Individual Competencies", "Integration in Educational Environment" and "Innovation". The following codes come into prominence under the "perceived usefulness and ease of use" theme: easy / fast access to information, attracts the student / increases attendance, easy to understand /learn, enhances / enriches the lesson, concretization, permanent learning, visualization, contribution to learning, opportunity of out-of-school learning and individual practice, system and service quality, classroom management, easy / fast access to information, and student / teacher communication. Moreover, form of use, internalization, copyright fees, system and service quality, storability, information / communication from the first source and content codes are also included in the ease of use theme. As a result of the study conducted by Çelik (2012), the codes "further perceived usefulness" and "ease of use" support the findings that the use of mobile technologies contributes to the increase in individual learning speed and enables learners to learn words at any time they desire without depending on their teacher, and that the mobile learning environment increases the motivation to learn. In another study, Williams (2009) stated that two examinations were held in scope of the study, which showed that the face to face learning group yielded a higher level of success compared to the mobile learning group. In the findings of their study, Kuzu, Çuhadar and Akbulut (2007) indicated that mobile learning provides access to knowledge and communication irrespective of time and place. In another study, it is noted that the use of mobile devices increases the interest in and motivation with the class. It is also noted that this provides more permanent learning as learners have the opportunity to learn whenever they want to, and their use of social media and mobile technologies has a positive effect on their performances and ensures easier management of learning processes (Ozan, 2013). In a study carried out by Korkmaz (2010) to examine the effect of problem- based mobile learning on academic achievements of students, it is revealed that the average of success scores of the mobile learning group is higher than those of the face- to- face learning group. These results match the "easy to understand/ learn", "permanent learning" codes in the study. The following codes come into prominence under the "attitude towards use and intention of use" theme: interest / attention / motivation, examples / areas of use, necessity, overuse and enriching / developing the class. Moreover, the opportunity of practice, examples, integration, student reaction, course preparation are included in the "attitude towards use and intention of use" theme. Y1ldirım's (2012) finding that educational games to be downloaded in mobile devices will increase student motivation and success in class and can be used as a useful teaching material match the "attitude towards use and intention of use" theme. The social effect theme consist of the following categories: peer, teacher, digital social environment and other environment. The effects of the following come into prominence within these categories: use by peers/ colleagues, use of mobile technologies by teachers in class for teaching purposes, inefficient use of mobile technologies by teachers, digital environments, digital social environment and workshops/ seminars attended by preservice teachers. Furthermore, the social effect theme included the following: use of mobile technologies with effective methods and techniques for teaching purposes, routine frequent use of mobile technologies for teaching purposes, and other social factors. The results of the study conducted by Ho, Hung, and Chen (2013) to examine the acceptance of mobile phone messages used to increase interaction between teachers and parents revealed that peers, family and superiors are major factors in the teacher's acceptance. It is emphasized in the study that opinions and expectations of families and friends have direct effect on the attitude towards behavior. This also matches the social effect codes in the study. The individual competencies theme consists of the categories: technical competency, 
professional competency, support and self- reliance. These categories include the following codes: technical knowledge, technical concern/ fear, technical support, educational support and self-confidence. In addition, past use of technology, form of use and knowing the examples are included in the individual competencies theme. Usluel and Seferoğlu (2004) emphasized that there are drawbacks in terms of knowledge, training and physical conditions which affect the use of technology in education by instructors. This coincides the "individual competencies" and "integration in educational environment" themes of preservice teachers. While referring to the challenges in the integration of instructors into the mobile educational environment in his study, Schoepp (2005) pointed out to the lack of technological standards, the unavailability of technology in the program content, inadequate application in the integration of education technology, and the failure in guiding instructors. Whereas, the "integration in educational environment" theme of preservice teachers consists of the categories: university and in-service training. The following codes come into prominence under the said categories: use of mobile technologies in class for teaching purposes, examples of teaching / activity / practice, adaptation to class and examples of activities. Moreover, university departments, in-service training perception and teaching methods and techniques are included in the "integration in educational environment" theme. In their study, Georgina and Ohson (2008) stated their opinion that the faculty is responsible for organizing a training on the use of technology for instructors at faculties. This coincides the opinions of preservice teachers on the integration of technology. Opinions of academicians on mobile learning environments developed by $3 \mathrm{G}$ technology, as reported in the study performed by Gündüz, Aydemir and Işılar (2011), yielded the results that applications cannot supersede teachers but can support the system, that the biggest challenge experienced in the transition to practice is the lack of qualified labor, that applications provide an independent learning environment irrespective of time and place, they are interesting and motivating, they provide easier access to information, they will increase success, and enable repetition of class and instant feedbacks. These results support the "attitude towards use and intention of use" and "individual competencies" themes of preservice teachers. The codes "follow-up of innovations" and "educational practices" come into prominence under the innovation theme. Also, study on course contents is included. The participants reported in the results of the study performed by Ozan (2013) that they preferred to receive social support mostly from their peers and management support mostly from instructors, which confirms the codes under the individual competencies theme. In another study, preservice teachers emphasizes that mobile technologies, mobile devices of the latest technology and wireless technologies are essential for learners to develop a more positive attitude towards mobile learning (Kuzu, Çuhadar and Akbulut, 2007).

\section{References}

Al-Senaidi, S., Lin, L., \& Poirot, J. (2009). Barriers to Adopting Technology For Teaching and Learning in Oman. Computers \& Education, 53(3), 575-590. https://doi.org/10.1016/j.compedu.2009.03.015

Büyüköztürk, Ş., Kılıç-Çakmak, E., Akgün, Ö. E., Karadeniz, Ş., \& Demirel, F. (2012). Bilimsel Araştırma Yöntemleri. Ankara: Pegem Akademi Yayıncılık.

Çelik, A. (2012). Yabancı Dil Öğreniminde Karekod Destekli Mobil Öğrenme Ortamının Aktif Sözcük Öğrenimine Etkisi ve Ögrrenci Görüşleri: Mobil Sözlük Örneği. Yayımlanmamıs yüksek lisans tezi. Gazi Üniversitesi Eğitim Bilimleri Enstitüsü.

Creswell, J. W. (2008). Educational Research: Planning, Conducting and Evaluating Quantitative and Qualitative Research. Boston: International Pearson Merril Prentice Hall.

Creswell, J. W. (2013). Research Design: Qualitative, Quantitative and Mixed Methods Approaches, Fourth edition. California: Sage.

Cropley, A. (2002). Qalitative research methods: An introducayion for students of psychology and education. Universty of Latvia

Donaldson, R. L. (2011). Student Acceptance of Mobile Learning. Unpublished dissertation, The Florida State University.

Garfield, M. (2005). Acceptance of Ubiquitious Computing. Information Systems Management, 22(4), 24-31. https://doi.org/10.1201/1078.10580530/45520.22.4.20050901/90027.3

Georgina, D. A., \& Olson, M. R. (2008). Integration of Technology in Higher Education: A Review of Faculty Self-perceptions. The Internet and Higher Education, 11, 1-8. https://doi.org/10.1016/j.iheduc.2007.11.002

Gündüz, Ş., Aydemir, O., \& Işıklar, Ş. (2011). 3G Teknolojisi ile Geliştirilmiş M-Öğrenme Ortamları Hakkında Öğretim Elemanlarının Görüşleri. Selçuk Üniversitesi Ahmet Keleşoğlu Eğitim Fakültesi Dergisi, 31,101-113. 
Ho, L. H., Hung, C. L., \& Chen, H. C. (2013). Using Theoretical Models to Examine the Acceptance Behavior of Mobile Phone Messaging to Enhance Parent-Teacher Interactions. Computers \& Education, 61, 105-114. https://doi.org/10.1016/j.compedu.2012.09.009

Korkmaz, M. (2010). Probleme Dayalı Mobil Öğrenmenin Öğrencilerin Akademik Başarılarına Etkisi. Yayımlanmamış yüksek lisans tezi. İstanbul Üniversitesi Fen Bilimleri Enstitüsü.

Kuzu, A., Çuhadar, C., \& Akbulut, Y. (2007). Reflections of Undergraduate Students Regarding PDA Use For Instructional Purposes. Selçuk University Journal of Social Sciences Institute, 18, 359-365.

Lincoln, Y. S., \& Guba, E. A. (1985). Naturalistic Inquiry. CA., Sage: Beverly Hills.

Martínez-Torres, M. R., Marín, S. L. T., García, F. B., et al. (2008). A Technological Acceptanceofe-Learning Tools Used in Practical and Laboratory Teaching, According to the European Higher Education Area. Behaviour ve Information Technology, 27(6), 495-505. https://doi.org/10.1080/01449290600958965

Mortenson, M. J., \& Vidgen, R. (2016). A Computational Literature Review of The Technology Acceptance $\begin{array}{llll}\text { Model. International Journal of } & \text { Information } & \text { Management, 36(6), } & \text { 1248-1259. }\end{array}$ https://doi.org/10.1016/j.ijinfomgt.2016.07.007

Ovčjak, B., Heričko, M., \& Polančič, G. (2015). Factors Impacting the Acceptance of Mobile Data Services-A Systematic Literature Review. Computers in Human Behavior, 53, 24-47. https://doi.org/10.1016/j.chb.2015.06.013

Ozan, Ö. (2013). Bağlantıcı Mobil Öğrenme Ortamlarında Yönlendirici Destek. Yayımlanmamış doktora tezi. Anadolu Üniversitesi Sosyal Bilimleri Enstitüsü.

Schoepp, K. (2005). Barriers to Technology Integration in A Technology-rich Environment. Learning and Teaching in Higher Education: Gulf Perspectives, 2, 1-24.

Tao, R., Huang, X., Wang, J., Zhang, H., Zhang, Y., \& Li, M. (2010). Proposed Diagnostic Criteria For Internet Addiction. Addiction, 105(3), 556-564. https://doi.org/10.1111/j.1360-0443.2009.02828.x

Usluel, Y. K., \& Seferoğlu, S. S. (2004). Öğretim Elemanlarının Bilgi Teknolojilerini Kullanmada Karşılaştıkları Engeller, Çözüm Önerileri ve Öz-yeterlik Algıları. Eğitim Bilimleri ve Uygulama, 3(6), 143-157.

Usluel, Y. K., Aşkar, P., \& Baş, T. (2008). A Structural Equation Model for ICT Usage in Higher Education. Educational Technology ve Society, 11(2), 276-273.

Van Raaij, E. M., \& Schepers, J. J. (2008). The Acceptance and Use of A Virtual Learning Environment in CHINA. Computers \& Education, 50(3), 838-852. https://doi.org/10.1016/j.compedu.2006.09.001

Wang, Y. S., Wu, M. C., \& Wang, H.Y. (2009). Investigating the Determinants and Age and Gender Differences in the Acceptance of Mobile Learning. British Journal of Educational Technology, 40(1), 92-118. https://doi.org/10.1111/j.1467-8535.2007.00809.x

Williams, P. W. (2009). Assessing Mobile Learning Effectiveness and Acceptance. Unpublished dissertation, The George Washington University.

Yeşilay, (2015). Teknoloji Bağımlılı̆̆ı. http://www.yesilay.org.tr/tr/bagimlilik/teknoloji-bagimliligiadresinden01.10.2015 tarihinde erişilmiştir.

Yıldırım, N. (2012). Yabancı Dil Eğitiminde Ĕgitsel Oyunlar Aracılı̆̆ıyla Mobil Öğrenme. Yayımlanmamış yüksek lisans tezi. Elazığ Üniversitesi Eğitim Bilimleri Enstitüsü.

Young, K. S. (1998). Internet Addiction: The Emergence of A New Clinical Disorder. Cyberpsychology \& behavior, 1(3), 237-244. https://doi.org/10.1089/cpb.1998.1.237

\section{Copyrights}

Copyright for this article is retained by the author(s), with first publication rights granted to the journal.

This is an open-access article distributed under the terms and conditions of the Creative Commons Attribution license which permits unrestricted use, distribution, and reproduction in any medium, provided the original work is properly cited. 